\title{
Analysing Speech Acts and Cooperative Principles in Helon Habila's Waiting for an Angel (2006)
}

\author{
Innocent Sourou KOUTCHADE, Michel DOSSOUMOU \& Gilbert ADENONMI \\ Université d'Abomey-Calavi, Bénin
}

\author{
*Corresponding Author: Innocent Sourou KOUTCHADE, Université d'Abomey-Calavi, Bénin
}

\begin{abstract}
The aim of this paper is to explore the types of speech acts and cooperative principles used in Helon Habila's Waiting for Angel(2006). In producing utterances, the speaker intends to perform various actions known as speech acts. This study focuses on the analysis of speech acts and cooperative principles in the novel under study through a mixed method approach. The findings reveal that representative 58(52.72\%) and directive 34(30.90\%) acts, are predominant and used by the main characters of the novel, Lomba and Alice.
\end{abstract}

Felicity conditions are also met in the analysed passages because the interactants are, in most cases, aware of the different issues being addressed in the discourse. The analyses also reveal the way interactants abideby the maxims guiding the cooperative principles which focus on what is needed at the relevant level of the conversation.

Keywords: Helon Habila, Speech Acts, cooperative principles, felicity conditions, maxims

\section{INTRODUCTION}

The post-independence era in Africa witnessed one form of self-inflicted debility or another, manifested in social decay, immiserization of the people, planlessness, slummization, thieveries of all stripes and hues with bad consequences for development. Military governments have worsened the situation in their well-choreographed race with their civilian collaborators that since denied the fruits of independence to the hapless and harried people of Africa. To chastise this fact, committed African writers belonging to a new generation have been denouncing these issues in their writing.

One of these writers is Helon Habila. In spite of their denunciation of these issues in their writings, good numbers of populations remain steadily both deaf and blind to the few but well- enlightened writers' yelling for awakening social conscience.

In order to decipher and decode the in-built meaning of language used in the literary works of these writers, one needs two challenging linguistic trends in vogue today: Systemic Functional Linguistics (SFL) and Pragmatics. By the way, the current article intends to scrutinize Helon Habilaes Waiting for an Angel (2006)through Searle's speech acts and Cooperative Principles. Indeed, the leading hypothesis of the work is that readers do not actually grab the very intent lurking behind the language of literature. Accordingly, our objective is to contribute to deciphering Helon Habila's in-built message so as to make the vital goal of pragmatics being to scavenge for and atomize the "invisible meaning" (Yule, 1996:127) potential of language. For that matter, the examination through pragmatics, this article derives support from an extract from the target novel to unveil manifestations of Helon Habila's unsaid intentions. Our foci of analysis revolve around presupposition, love, speech act, Cooperative Principle, and conversational implicature.

\section{THEORETICAL FRAMEWORK}

\subsection{Pragmatics: Definition and Goals}

Pragmatics is a branch of modern linguistics approaching language from a mostly functional perspective. It is the study of invisible meaning (Yule 1996: 127), the science of the unsaid (Mey 2001:1994), the study of meaning as it "emerges in language use" (Marmaridou 2000:1), and the 
study of linguistic acts and communicative actions and their appropriateness (Bublitz 2009; Van Dijk 2008; Fetzer 2004,2007). In a word, pragmatics is concerned with a context-dependent use and utilityoriented interpretation of language. For Leech (1983:X), it is "the study of how utterances have meaning in situations". As regards the goal of pragmatics, it functions to set into open what Yule (1996:127) calls the "invisible meaning" and Horn \& Ward (2006: 1) also terms as the "meant-butunsaid.

\subsection{Context and Common Ground}

The context of linguistic text is a set of both cultural and situational conditions guaranteeing the texture of the latter. Indeed, discourse context is vital to meaning negotiation and encompasses both material and immaterial facets. Potts (2014:2) conceives common ground as "world knowledge more immediate information characterizing where we are and what goal we have, our beliefs about each other, our beliefs about those beliefs". Definitely, the common ground of every act of communication is a matter of discourse participant agreement enacted through modulating the ordinarily expectable impacts of context on language use.

\subsection{Presupposition, Conversational Implicature, and Inference}

The concept of presupposition is defined as a proposition or inference of which truth is taken for granted in the utterance of a sentence. It refers to what a speaker assumes is true or known by the hearer for being the case a priori (Yule,1996:132). For Dekker (2008:25), "presupposition are kind of preconditions for linguistic items (expressions) or acts (utterances) to make sense". Stockwell (2007:232) also contends that the presupposition of a statement $\mathrm{P}$ is something which has to be true before $\mathrm{P}$ can possibly be a plausible thing to say. As to conversational implicature, it is any meaning implied or expressed by, and inferred or understood from, the utterance of an utterance which is meant without being part of what is strictly said. It is derived via Grice's $(1975,1989)$ cooperative principle and its attendant maxims of conversation. Yule (1996:134) claims that it is the indirect or implicit meaning of an utterance as derived from the speech context and which is absent from its conventional use. Concerning the concept of inference, it is an addressee- centered type meaning negotiation and deal with what the latter happens to understand by what is said to him/her. Gumperz (1982:2) refers to it as the "The ability to see beyond surface content". To recapitulate, let's say that effective communication occurs only when the presupposition-implicature-inference tandem operates a functionally harmonious trade and allow mutually attuned negotiation.

\subsection{Speech Acts and Felicity Conditions}

For Traugott \&amp; Pratt (1980:229), the spearhead-works relating to the Speech-Act Theory are Austin(1962) ad Searle (1969). Kryk-Kastovsky (2006: 534) claims that Speech Acts are utterances whereby by saying something the speaker performs certain acts classifiable into performances and constatives. This means that people use language to do something real. This quote also calls for the claim that" Speech acts are actions performed via utterances". (Yule, 1996:47). Besides, Searle (1969:16) contends that "Speaking language is performing speech acts, acts such as making statements, giving commands, asking questions, making promise, and so on". Moreover, after discovery, Austin reconsidered the concept of saying something is doing something and eventually came up with the idea that in producing an utterance a speaker performs three acts simultaneously: the locutionary act (the mere act of saying something or making a pronouncement), the illocutionary act (the verbal acts in-built intention) and the perlocutionary act (its manifest impact). They respectively hold some forces with reference to their individual in-built goals. We can grasp mentally that the first two are under the speaker control while the third is under the hearer control. Thence, we can conclude that there is communication when there is a good match between illocutionary and perlocutionary forces.

Going in further details, Searle (1969) has broken up the sub-concept of the illocutionary force into five different variants to which are attached individual missions as illustrated in table 1 below: 
Table1. Illocutionary forces and ontological missions

\begin{tabular}{|l|l|}
\hline \multicolumn{1}{|c|}{ Illocutionary forces } & \multicolumn{1}{c|}{ Ontological missions } \\
\hline Representatives & $\begin{array}{l}\text { To represent a state of affairs, or to mean that something is the case. Examples: } \\
\text { stating, claiming, hypothezing, describing, predicting, suggesting, insisting, or } \\
\text { swearing. }\end{array}$ \\
\hline Expressives & $\begin{array}{l}\text { To express the speakeres state of mind or psychological attitude towards a given } \\
\text { situation. Examples: congratulating, thanking, deploring, condoling, welcoming, } \\
\text { greeting, etc. }\end{array}$ \\
\hline Directives & $\begin{array}{l}\text { To get the addressee to do something. Examples: requesting, commanding, } \\
\text { pleading, inviting, questioning, urging, or suggesting someone to do something }\end{array}$ \\
\hline Commissives & $\begin{array}{l}\text { To commit the speaker to doing something. Examples: promising, threatening, } \\
\text { vowing. }\end{array}$ \\
\hline Declarations & $\begin{array}{l}\text { To bring about the state of affair they refer to. Examples: blessing, firing, } \\
\text { baptizing, bidding, passinga verdict, arresting, or marrying. }\end{array}$ \\
\hline
\end{tabular}

Besides, for the performance of a speech to be recognized as intended, it needs to satisfy a series of conditions, technically known as felicity conditions. It is notable that ordinary people automatically accept the felicity conditions when they communicate. To be felicitous, illocutionary acts need to be produced (and interpreted) in accordance with felicity conditions. The truth value of an utterance is what proves it sensible. It definitely builds on Felicity or Appropriateness Conditions. Thence, an utterance which does not satisfy the felicity conditions cannot function as a valid instance of the typeof speech acts to which they apply.

By the way, whenever a speech act grounds on appropriateness conditions, it is deemed felicitous. If not, it is conceived of as infelicitous or inappropriate. Drawing on the Searle's taxonomy and handling on apology case. Meyer 2009:53) itemized such conditions into four major types as shown in table 2:

Table2. Interfaces of the Felicity Conditions

\begin{tabular}{|l|l|}
\hline Conditions & Functional essence \\
\hline $\begin{array}{l}\text { Propositional } \\
\text { condition }\end{array}$ & $\begin{array}{l}\text { The speaker expresses a regret for a past act A that } \\
\text { he/she committed in disfavor of } \\
\text { his/her addressee. }\end{array}$ \\
\hline $\begin{array}{l}\text { Preparatory } \\
\text { condition }\end{array}$ & $\begin{array}{l}\text { The speaker believes that his/her act has hurt the } \\
\text { addressee. }\end{array}$ \\
\hline Sincerity condition & $\begin{array}{l}\text { The speaker frankly regrets his/her act and is not } \\
\text { hypocritical at all }\end{array}$ \\
\hline Essential condition & $\begin{array}{l}\text { What the speaker says really counts as an apology and } \\
\text { is nothing jocular }\end{array}$ \\
\hline
\end{tabular}

\subsection{Cooperative Principle (CP)}

In 1975, the British philosopher H.P. Grice came out with the fundamental principles governing conversational exchanges. His fundamental conclusion was that conversational exchanges are governed by an overarching principle, which he named the Cooperative Principle. People usually cooperate with each other in their daily interactions by observing certain rules or maxims.

Communication is made possible as a result of interlocutor's mutual cooperation. Grice was the first to talk about cooperation in relation to the act of linguistic communication. He proposes a general principle which communicators are expected to observe. Grice (1975: 46) observes: "Make your conversational contribution such as is required, at the stage at which it occurs, by the accepted purpose or direction of the talk exchange in which you are engaged". Moreover, he itemizes his CP into a set of four maxims known as maxims of conversation:

$\Delta$ Maxim of quality: Contribute only what you know to be true. Do not say false things or things for which you lack evidence. Thus, we can infer that this maxim is oriented towards imparting moral virtues onto our utterances.

$\Delta$ Maxim of quantity: Make your contribution as informative as required. Do not say more or less than is required. This maxim aims at sparing language users from both pointless raving or diversionary prolixity and untimely taciturnity. 
Maxim of relation/relevance: Make your contribution relevant; that is, say what is expectedly attuned with the prevailing discourse context.

A Maxim of Manner: Avoid linguistic obscurity, ambiguity, be brief, and orderly.

\section{Pratical Analysis OF The EXTRACT UNDER Study}

Our practical analysis will revolve around three major points. The very first of them includes the manifestations of speech acts throughout the extract. Our second step will be of importance to deixis while our last focus concerns conversational implicature.

\subsection{Analysis and Interpretation of Speech Acts throughout the Extract}

\subsubsection{Speech Act Identification in the Extract}

This extract is the conversation which has taken place between Alice and Lomba, first of all on the campus, in Lomba's hostel and in Alice's flat.

Here, we have adopted Searle (1975) "es taxonomies of illocutionary speech acts. The identification of speech acts is carried out with the following keys and summarized in table 3:

Reading keys:

$\mathrm{R}=$ Representative $; \mathrm{D}=$ Directive $; \mathrm{C}=$ Commissive $; \mathrm{Dec}=$ Declaration; $\mathrm{E}=$ Expressive

Table3. Itemized overview of illocutionary-force shades

\begin{tabular}{|c|c|c|}
\hline $\mathrm{N}^{0}$ & Utterances & Characters \\
\hline 1 & „,My first day in school“.,,Iamnervous((R)). & \multirow{3}{*}{ Alice } \\
\hline 2 & Let us go and sit there(D). & \\
\hline 3 & Is the lecturer here yet?(D) & \\
\hline 4 & ,What happened?(D) & \multirow[b]{2}{*}{ Lomba } \\
\hline 5 & $\begin{array}{l}\text { I thought you had dropped out before you" deven } \\
\text { started."(D) }\end{array}$ & \\
\hline 6 & I"ve been looking for a place $(\mathbf{R})$ & \multirow[b]{4}{*}{ Alice } \\
\hline 7 & My Dad doesn"t want me to stay in the hostels $(\mathbf{R})$. & \\
\hline 8 & Aflatcloseto school(R). & \\
\hline 9 & And you, where do you stay(D) & \\
\hline 10 & ,In the hostels." $\left(\mathbf{R}^{\prime \prime}\right)$ & Lomba \\
\hline 11 & ,The driver will be back soon $(\mathbf{R})$. & \multirow[t]{6}{*}{ Alice } \\
\hline 12 & Let us walk to the road and wait for him."(D) & \\
\hline 13 & „Come and have dinner $(\mathbf{D})$ & \\
\hline 14 & I"ll cook.(C). & \\
\hline 15 & „Lomba, I was just about to go( $\mathbf{R})$ & \\
\hline 16 & I was passing and I stopped to sayhi," $(\mathbf{R}))$ & \\
\hline 17 & We left in a rush this morning.(R) & \multirow[t]{4}{*}{ Lomba } \\
\hline 18 & We were late for202.(R) & \\
\hline 19 & „Sit down $(\mathbf{D})$, & \\
\hline 20 & „letme getyoua coke."(D) & \\
\hline 21 & „OK" ( C) & Alice \\
\hline 22 & „Your Coke." $(\mathbf{D})$ & Lomba \\
\hline 23 & „Thanks ${ }^{\text {e" }}(\mathbf{E})$ & Alice \\
\hline 24 & „Diana Ross, You like her?“(D) & Lomba \\
\hline 25 & „My favourite,"Upside Down”."(R)" & Alice \\
\hline 26 & „Iprefer“Endless Love”, with Lionel Ritchie(E) & \multirow[t]{2}{*}{ Lomba } \\
\hline 27 & $\begin{array}{l}\text { But she can"t singlike Millie Jackson, or Betty } \\
\text { Wright }(\mathbf{R}) \text {. }\end{array}$ & \\
\hline 28 & „Idisagree(E) & \multirow[t]{2}{*}{ Alice } \\
\hline 29 & She has more class $(\mathbf{R})$. & \\
\hline 30 & „But lesssoul”( & Lomba \\
\hline 31 & $\begin{array}{l}\text { „My father"s favourites are Sam Cooke and Otis } \\
\text { Redding }(\mathbf{R})\end{array}$ & \multirow[t]{2}{*}{$\begin{array}{l}\text { Alice } \\
\text { Alice }\end{array}$} \\
\hline 32 & I grew up listening to them $(\mathbf{R})$ & \\
\hline
\end{tabular}




\begin{tabular}{|c|c|c|}
\hline 33 & My father was just crazy about soul music( R). & \\
\hline 34 & $\begin{array}{l}\text { He bought stacks of their records when he was in } \\
\text { America...(R) }\end{array}$ & \\
\hline 35 & I have them now $(\mathbf{R})$ & \\
\hline 36 & $\begin{array}{l}\text { He gave them to me, complete with the turntable } \\
\text { (R). }\end{array}$ & \\
\hline 37 & I guess he is a bit too old for soul music now $(\mathbf{E})$ & \\
\hline 38 & „You never get too old for good music(R)." & \multirow[t]{2}{*}{ Lomba } \\
\hline 39 & „My write-up, it came out last week $\left.{ }^{\prime \prime}(\mathbf{R}).\right)$ & \\
\hline 40 & $\begin{array}{l}\text { "The Military in Nigeria Politics", My father is a } \\
\text { soldier." }(\mathbf{R})\end{array}$ & Alice \\
\hline 41 & „I know I am not condemning them all(R)." & Lomba \\
\hline 42 & „That is not what I mean $(\mathbf{R}),^{c e}$ & Alice \\
\hline 43 & „What do you mean?(D) $)^{\mathrm{ec}}$ & Lomba \\
\hline 44 & $\begin{array}{l}\text { I just wanted to see you and may be say sorry for the } \\
\text { Other day }(\mathbf{C})^{\prime c} \text {. }\end{array}$ & Alice \\
\hline 45 & Now I have to go(C). & \\
\hline 46 & $\begin{array}{l}\text { „May be after today you won }{ }^{\text {eet }} \text { avoid me so much in } \\
\text { class }{ }^{\text {ee }}(\mathrm{R}), \text {. }\end{array}$ & \\
\hline 47 & $\begin{array}{l}\text { „If you are going back, you don }{ }^{e c} \text { t have to take abus ( } \\
\text { D), }\end{array}$ & Lomba \\
\hline 48 & $\begin{array}{l}\text { There is a path through the fence that takes you there } \\
\text { In about ten minutes }{ }^{\text {ee }}(\mathrm{R})\end{array}$ & \\
\hline 49 & Let me show you(D)." & \\
\hline 50 & „In ever knew this shortcut existed,(R) & Alice \\
\hline 51 & „I discovered it the day I went to your place(R), & Lomba \\
\hline 52 & Here we are, $(\mathrm{R})^{\mathrm{ee}}$ & \\
\hline 53 & $\begin{array}{l}\text { „Well, come in and listen to some of my soul } \\
\text { records(D) - }\end{array}$ & Alice \\
\hline 54 & I have lots and lots of them(R), & \\
\hline 55 & „Sit down ${ }^{e e}(\mathrm{D}),{ }^{e e}$ & \\
\hline 56 & They are all new!ee $(\mathrm{R})$ & Lomba \\
\hline 57 & „Well preserved(R) & Alice \\
\hline 58 & My father bought them before I was born $(\mathrm{R}) .^{c e}$ & \\
\hline 59 & „Let"es playt hem, ${ }^{\text {ee }}(\mathrm{D})$ & Lomba \\
\hline 60 & „The player is in the bedroom $(\mathrm{R})$. & \\
\hline 61 & I play them when I can ${ }^{\text {ee }}$ sleep(R). & \\
\hline 62 & Let $^{\text {ee }}$ goin. ${ }^{\text {ee }}(\mathrm{D})$ & \\
\hline 63 & „Don ${ }^{e e} t$ worry(D), & \\
\hline 64 & I am all alone $(\mathrm{R})$ & \\
\hline 65 & My flatmate has gone on a journey(R).e & \\
\hline 66 & „Sorry about the mess,(E) & \\
\hline
\end{tabular}




\begin{tabular}{|c|c|c|}
\hline 67 & But I never planned to have any one in here(R)." & \\
\hline 68 & .Do you think that is true?(D) ${ }^{\text {ee }}$ & \\
\hline 69 & „What?"e(D) & Lomba \\
\hline 70 & „Do you believe a man in love is so naïve?(D) & Alice \\
\hline 71 & $\begin{array}{l}\text { „Does here ally do all those things the song says?"e( } \\
\text { D). }\end{array}$ & \\
\hline 72 & „,I wouldn't know(E). & Lomba \\
\hline 73 & I guess most people inlove might be like that (E)." & \\
\hline 74 & „No, I am talking about you(R)." & Alice \\
\hline 75 & „It has never happened to me(R).“ & Lomba \\
\hline 76 & „You mean you ${ }^{\text {"e ve never been inlove? }}$ (D) & Alice \\
\hline 77 & „I" ve mostly admired, but not really loved.(R) & Lomba \\
\hline 78 & „Not really loved(R). & Alice \\
\hline 79 & How old are you?(D) $)^{c e}$ & \\
\hline 80 & „Ahundredth is birthday. ." $(\mathrm{R})$ & Lomba \\
\hline 81 & „Serious(R). & Alice \\
\hline 82 & „OK. Twenty-two(R). & Lomba \\
\hline 83 & „Same here(R). & Alice \\
\hline 84 & „But what have you been doing all this while?"(D) & \\
\hline 85 & „Waiting for you, of course ${ }^{e e}(\mathrm{R})$ & Lomba \\
\hline 86 & „I am listening $(\mathrm{R}) .^{c}$ & Alice \\
\hline 87 & $\begin{array}{l}\text { „I did not know I was waiting for you, of course, } \\
\text { (R) }\end{array}$ & \\
\hline 88 & $\begin{array}{l}\text { But the very first day I saw you I knew I had been } \\
\text { Waiting for you (R). }\end{array}$ & \\
\hline 89 & Why?(D) & \\
\hline 90 & I don"t know (E). & \\
\hline 91 & $\begin{array}{l}\text { But sometimes you meet someone and they are } \\
\text { everything you'ce ever imagined and desired in a }\end{array}$ & \\
\hline \multirow[t]{2}{*}{92} & Any body else apart from them would be imperfect ( & \\
\hline & E). & \\
\hline 93 & It is true $(\mathrm{R}) .^{. e}$ & \\
\hline 94 & „And I was perfect for you? & \\
\hline 95 & „How time flies!(E) & \\
\hline
\end{tabular}




\begin{tabular}{|c|c|c|}
\hline 96 & It is after eight already(R). & \\
\hline 97 & You must be very hungry(E), & \\
\hline 98 & And I am afraid I have no food in the house (E). & \\
\hline 99 & „Only coke, or tea if you prefer (D). & \\
\hline 100 & „I think I should be going $(\mathrm{E}) .^{c e}$ & Lomba \\
\hline 101 & „Why?(D) & \\
\hline 102 & $\begin{array}{l}\text { Do you have something pressing to do in the hostel?( } \\
\text { D) }\end{array}$ & \\
\hline 103 & You could spend the night and go early (D).e & \\
\hline 104 & „I thought you were never going to do that. ${ }^{\text {ee }}(\mathrm{E})$ & \\
\hline 105 & „What are you going to do after your school?"e $(\mathrm{D})$ & \\
\hline 106 & „I'llbe come a writer." $(\mathrm{R})$ & Lomba \\
\hline 107 & „You mean a journalist? ${ }^{c e}(\mathrm{D})$ & Alice \\
\hline 108 & „No, a writer(R) & Lomba \\
\hline 109 & „Promise?"e(D) & Alice \\
\hline 110 & 'Promise $(\mathrm{R})$ & Lomba \\
\hline
\end{tabular}

\subsection{Data Analysis in the Extract}

\subsubsection{Statistical Analysis}

Basing on the above speech identification, we have decided to reconsider the different speech acts both quantitatively and qualitatively. The quantitative analysis enables me to count the frequency of speech acts of each interactant and provide the related percentage of these pragmatic features. The results are displayed in table 4 below

Table4. Distribution of Speech Acts uttered by Lomba and Alice

\begin{tabular}{|l|l|l|l|}
\hline \multicolumn{2}{|l|}{ Interactants } & Totalandpercentage \\
\hline Speechacts & Lomba & Alice & Percentage \\
\hline Representatives & 26 & 32 & $58(52.72 \%)$ \\
\hline Directives & 11 & 23 & $34(30.90 \%)$ \\
\hline Comissives & 00 & 04 & $04(3.63 \%)$ \\
\hline Expressives & 06 & 08 & $14(12.72 \%)$ \\
\hline Declarations & 00 & 00 & $00(00 \%)$ \\
\hline Total & 42 & 65 & $110(100 \%)$ \\
\hline
\end{tabular}

The above passage is a conversation between Lomba and Alice. From the table above, we can notice that out of a total of one hundred and ten (110) speech acts , there are fifty-seven (58) representatives, which stands for $58.72 \%$ of the total. In addition, out of the fifty-eight representatives, Lomba has produced twenty-six (26) but Alice has used thirty-two (32). The predominance of these representatives means that the two characters state what they believe is true or not. They use the representatives to represent some state of affairs, and the world as they believe it. They also express their beliefs through assertions, conclusions and descriptions.

Likewise, directives come second as they are thirty-four (34) out of one hundred and ten 110 utterances. They represent $30.90 \%$ of the total number of the utterances in the excerpt. However, Alice has used more directives than Lomba in the extract. The important number of directives 
suggests that the two characters, Lomba and Alice are concerned with getting each other to do something. These are expressed in form of advice, commands, orders, questions and requests and suggestions. In addition, the expressives rank third (14).They represent $12.72 \%$ of the total. What is noticeable here is that Lomba and Alice share almost the same number of expressives in the conversation. This means that both of them are concerned with expressing a psychological attitude or state. We can deduct from this remark that Lomba and Alice share the same degree of feeling. Declarations are non-existent in the extract, whereas commissives are in few proportions. Lomba has produced no commissive in his utterances. This means he commits himself less to some future actions than Alice. He is less concerned with undertaking to make the world match his words than Alice does.

Now, we focus on the qualitative aspects of the analysis. This consists in dealing with a few instances of speech acts in extract 1 :

4-,, What happened? (D) 5-I thought you had dropped out before you eed even started." ( E) 6-,II"ve Been looking for a place( R). 7-My Dad doesn"t want me to stay in the hostels(R).8- A flat close to school( R)

The above passage is Alice's answer to Lomba's question : 4-,, What happened? (D) ,a directive speech act which is intended to get Alice to provide Lomba with information related to her failure to attend the lecture. Alice's utterances show that she is committed to saying what she considers to be the truth. She asserts, reports and concludes. As the statistics table shows, Alice utters more directives than Lomba does. The following examples are illustrative:

"68-Do you think that is true? (D)" she asked suddenly, opening her eyes, catching him staring intently at her face.) 70- , Do you believe a man in love is so naïve?(D) 71-Does he really do all those things the song says?ee (D) Suddenly his mind flashed to a vision of her in the mullato's arms, the wet kiss.

These sequences of directive speech acts show that the main concern of Alice is to get Lomba to give his opinion about what the song entitled „When a Man Loves a Woman' says.

Moreover, the significant number of expressive speech acts in the text include the following:

$72-$,I wouldn"t

know(E).

73-I guess most people in love might be like that ( E)

104-,I thought you were never going to do that." (E)

The first two utterances are produced by Lomba to tell Alice that he believes a man in love is so naïve. The third one is produced by Alice to show Lomba that she likes his kissing.

The few commissives in the excerpt include the ones below:

$21-,, \mathrm{O} \mathrm{K}$

(C)

44-,,I just wanted to see you and maybe say sorry for the other day (C) ${ }^{e e}$,

The above utterances are produced by Alice. She uses them to make Lomba not avoid her.

\subsubsection{Analysing the Categories of Speech Acts}

To make the occurrence of the speech acts in the extract clearer, we have recapitulated them with the sentences in which they are produced in Table 5 and Table 6 below.

Table5. Speech Acts occurrence in Lomba's utterances

\begin{tabular}{|l|l|l|l|l|l|}
\hline $\begin{array}{l}\text { Speechacts } \\
\text { category }\end{array}$ & Representatives & Directives & Commissives & Expressives & Declarations \\
\hline Number of & $10,17,18,24$, & $4,5,19,20,22$ & & $26,72,73,90$ & \\
sentences & $27,30,38,39$ & $, 43,47,49$, & & $, 92,100$ & \\
& $, 40,42,48,51$, & $59,69,89$ & & & \\
& $52,56,75,77$, & & & & \\
& $80,82,85,87$, & & & & \\
& $88,91,93,106$ & & & & \\
& $, 108,110$ & & & & \\
\hline
\end{tabular}


Table6. Speech Acts occurrence in Alice's utterances

\begin{tabular}{|l|l|l|l|l|l|}
\hline $\begin{array}{l}\text { Speechacts } \\
\text { category }\end{array}$ & Representatives & Directives & Commissives & Expressives & Declarations \\
\hline $\begin{array}{l}\text { Number of } \\
\text { sentences }\end{array}$ & $1,6,7,8,11$, & $2,3,9,12,13$, & $14,21,44,45$ & $23,28,37,66$, & \\
\hline & $, 31,32,33$, & $, 68,70,71$, & & $95,97,98$, & \\
& $34,35,36,41$ & $76,79,84,94$ & & 104 & \\
& $, 46,50,54$, & $, 99,101,102$, & & & \\
& $57,58,60,61$ & $103,105,107$, & & & \\
& $, 64,65,67$, & 109 & & & \\
& $74,78,81,83$ & & & & \\
& $, 86,96$. & & & & \\
\hline
\end{tabular}

From the above tables, the sentences showing each speech act are clearly introduced. We consider them again in the context of the conversation between Alice and Lomba in the extract.

\subsection{Analysis of Conversational Implicature in the Excerpt from Waiting for an Angel by Helon}

\section{Habila}

\subsubsection{The Non-observance of Maxims in the Extract}

The Non-observance of Maxim of Quantity in the Extract

\section{Conversation One}

Alice: 1-,,My first day in school ${ }^{\mathrm{ee}}$.,I am nervous . 2-Let us go and sit there .3- Is the lecturer here yet?

Lomba : 4-,, What happened? 5-I thought you had dropped out before you ${ }^{\text {ee }}$ even started."

Alice: 6-,I' close to school. 9- And you, where do you stay?

Lomba: $10-$,In the hostels. ${ }^{\text {ee }}$

Lomba is supposed to be as informative as required while answering Alice"s question about the lecturer. Here, he is less informative than required because he does not tell Alice that the lecturer has come , lectured and left. He violates the maxim of quantity. „I thought you dropped out before you'd even started' implies that Alice is not a serious student.

The Non-observance of Maxim of Quality in the Extract

\section{Conversation Three}

Alice: 78-,,Not really loved.79-How old are you?

Lomba: 80-,, A hundred this birthday."

Alice:81-,,Serious.

Lomba has violated the maxim of quality in the conversation above because „he lies or says something that is believed to be false'. Lomba wants to mislead Alice by stating in (80):,,A hundred this birthday'. He has violated the second maxim of cooperative principle to impress Alice. He does not give an answer that is logically based on what he believes and what makes it be an appropriate information. Lomba"s reply implies: „I don't want to tell you my real age'.

\section{DISCUSSION OF THE FINDINGS}

\subsection{Speech Acts}

\subsubsection{Representatives}

The findings reveal that out the 58 representatives, Lomba has used 26 and Alice 32. As the daughter of a general, she uses representatives to tell Lomba that her father who is a member of the Military objected to her staying in hostels. Her father knew that she stayed in hostels, she may be victim of 
studentse incessant riots and strikes. He was certainly informed by the strike students were planning in all the Federal Universities across the country under the leadership of Sankara. Moreover, she uses the representatives to tell Lomba about her father enthusiasm with soul music. Lomba, a young journalist in Lagos, under the brutal military regime of Nigeria, is also enthusiastic with soul music, girls and the novel he is writing. Instead of using representatives to represent a state of affairs, or to mean that something is the case, she used them to affect the behavior of Lomba.

\subsubsection{Directives}

Alice has used more directives than Lomba. Out of the 34 directives, the number used by herranks 23 and the one of Lomba is 11.Alice employed this number of Directives when Lomba meets her in the university. As the long awaited angel, Lomba meets her and become lovers. She also used them when she invited him to come and have dinner in her flat. Moreover, they are employed by her to seduce him. Since Marriages were often arranged among young people, even though it was becoming less common (Nwabara $10 \&$ Falola, Culture 119). Though premarital sex was (and still is) not looked upon kindly (Nigerian Society and Culture), her undergraduate level and the love she has for him (Lomba) makes her break this cultural belief.

\subsubsection{Commissives}

As regards the commissives, only Alice employed the four ones found in the extract. First she uses it to commit herself to cook dinner for Lomba. Second, she employs it to accept the coke Lomba offers her. Third, she utters it to apology for being kissed by one of her male friend before Lomba the day he called on her in her flat. The use of all these commissives testify that she loves Lomba but not Ngai, a military man many year older than her. Yet, she has to marry Ngai because she needed the money to cope with the bills and carter for her mother who was suffering from breast cancer.

\subsubsection{Expressives}

Out of the 14 expressives found in the excerpt, Lomba and almost use the same number. Since the expressive express the speaker's state of mind or psychological attitude towards a given situation; this shows that they love each other. She is a girl Lomba loved so much and wanted to marry but the moment the school was closed down; they were forced to go their separate ways. Lomba only met her again in a hospital where she was taking care of her sick dying mother.

\subsection{Cooperative Principle}

As regards Grice's maxims, the findings reveal that the novelist has made the characters fail to observe the Cooperative Principle and Grice's maxims for specific purposes. The maxim of quality is one of the maxims that Lomba has violated to impress Alice. The second maxim i.e the maxim of quantity has not been observed by Lomba while replying Alice question because the novelist purpose in this conversation is to make the reader be aware of Alice's non seriousness.

\section{CONCLUSION}

This research work was premised on scrutinizing an aspect of meaning in context in Helon Habila's Waiting for An Angel (2006). It has focused on what speakers intend to do with their utterances and how the hearer infers the different intentions and also looks at the general principles that guide the different inferences that are drawn upon. It must be admitted that context plays an important role in the interpretation of utterances.

Moreover, this study helps us to understand that conversation is facilitated by the co-operative principle which relies on four important maxims, rules which are involved in a conversation or speech exchange, normally assume to be in place and this makes a coherent, directed interchange possible. Then, understanding speech acts principles of conversational exchanges and being aware of immediate local context of the extract under study helps to grasp the main issue raised in it. In regards of the revelations of this study, we once again have evidence that our initial leading research hypothesis that "readers don't actually grab the very intent lurking behind the language of literature" has turned out valid, given the hidden meanings imposed on language in the excerpt. 


\section{REFERENCES}

[1] Akogbeto, P.\& Koutchadé I. (2014) „Pragmatics Analysis of Amma Darko“s Beyond the Horizon“e Multifontaines 1, 55-71.

[2] Austin, J.L.(1962). How to Do Things With Words. Cambridge (Mass): Harvard University Press.

[3] Austin, J.L.(1969).Performative Constative, an essay in the philosophy of Language. Cambridge: Cambridge University Press.

[4] Deborah, B. O.(2011). "Socio-political and economic alienation in HelonHabila"s Waiting for an Angel". Unpublished dissertation. University of Ilorin, Ilorin

[5] Koussouhon,L.,\& Guézohouèzon, M. (2016). Human Comedy in Wole Soyinka"s Jero"s metamorphosis: A Pragmatic Analysis.IRA International Journal of Education and Multidisciplinary Studies (ISSN 24552526),4(1).

[6] Levinson,S.(1983). „Deixis ${ }^{\text {se }}$ in Pragmatics. Cambridge: Cambridge University Press

[7] Mey,J.L.(1993). Pragmatics: An Introduction. Oxford: Blackwell Publishing.

[8] Pratt, M.L. (1977). Towards a speech-Act Theory of Literary Discourse. Bloomington: Indiana University Press

[9] Peccei, J.S.(1999). Pragmatics. London and New York: Routledge.

[10] Qadir, A., \& Riloff , E.(2011).Classifying Sentences as Speech Acts in Message Board Posts. Proceedings of the 2011 Conference on Empirical Methods in Natural Language Processing (EMNLP 2011).

[11] Saeed, J.I.(1997).Semantics. New York: Blackwell

[12] Searle, J.(1969). Speech acts. Cambridge: Cambridge University Press.

[13] Thomas, J. (1995).Meaning in interaction: An introduction to pragmatics. London: Longman

[14] Uwasomba, C.(2014).Helon Habila: Narrating the Dysfunctional Baggage of a Post-Colony. The Journal of Pan African Studies, 6(7).

[15] Yule, G.(1996). Pragmatics. New-York: Oxford University Press.

[16] Yule, G.(2007). The Study of Language. ( 7 th edn) Cambridge : Cambridge University

Citation: Innocent Sourou KOUTCHADE et al. " Analysing Speech Acts and Cooperative Principles in Helon Habila's Waiting for an Angel (2006)" International Journal of Humanities Social Sciences and Education (IJHSSE), vol 8, no. 7, 2021, pp. 86-96. doi: https://doi.org/10.20431/2349-0381.0807010.

Copyright: () 2021 Authors. This is an open-access article distributed under the terms of the Creative Commons Attribution License, which permits unrestricted use, distribution, and reproduction in any medium, provided the original author and source are credited. 